\title{
Folklorisation and Reoralisation in Context: Some Narratives on the Current Challenges facing South Africa's Migrant Labourers
}

MASOGA, Magomme A.

\section{Abstract}

Tris his paper evolved as a result of reading a special note of condolences scribed by two women who are in a polygamous marriage situation from Chikhutu village in Malawi, in 2005. The note was signed by these women as 'Mama Luhanga and Mama Luhanga,' the wives of Dada Patson Luhanga, a migrant worker, based in South Africa, with a very strong linguistic, social and cultural background of Tumbuka. The note was meant to 'comfort and support' the South Africa based widow, Mme Nanabi Kegakilwe, who lost her husband. Dada Patson Luhanga has been staying on the compound of the late Rre Enoch Kegakilwe for more than twelve years. The existing verbal agreement is that Dada Luhanga will work on the Kegakilwe garden every Saturday of the week, while doing other menial jobs on other days around Midrand in South Africa. As per this agreement, Dada Patson Luhanga was offered accommodation at the Kegakilwe compound pro-bono. Expressly, the note reveals and exposes pains, hurts, and frustrations currently experienced by migrant labourers in South Africa. Recently in South Africa, the crisis of xenophobia, or Afrophobia as some critics prefer to call it, and related spates of violence, add to this challenge. The paper aims to discuss some current South Africa's migrant labourers' challenges by making use of theories of folklore and orality. It will use a method of discourse analysis in reading the note and analysing its appropriate hermeneutics of power and identity.

Keywords: migrant workers, folklorisation, reoralisation, Malawi, South Africa. 


\section{Introduction}

Undeniably, the current South African socio-political and economic landscaping has become interesting for any human and social science research analysis. Some time ago the country witnessed the sad story of Afrophobia in South Africa, stemming from 2008, with a recurrence in 2015. The conclusion of the Marikana killings left many unanswered questions. In fact, there are mixed feelings in terms of how 'correction' should be applied in this case. There is consensus that their current South African situation has become complex. New issues and challenges have emerged. An HIV/Aids pandemic remains a challenge. Poverty and unemployment remain stubbornly high. The economic storm clouds are far from disappearing. Crime is not only soaring, but increasingly violent. There is a pervasive air of public corruption. Often one notes with a sense of disappointment that even some South African democratic institutions are battered. The abuse of children, women and the aged has reached terrifying levels. In some cases, one finds that communities are paralyzed by the feeling of anxiety, drift and foreboding of imminent collapse among communities. Spate of violence and protests by communities across the country against sluggish governments delivery of public services, indifferent officials and corruption are also likely to continue. It is giving a strong sense of uncertainty, discontentment and doubt. It is all pervasively a state of restlessness. While one agrees with generalised comments raised on the South Africa's 'growing democracy' but one is inclined to read that there is a level of dissatisfaction and disappointment among communities.

In a stimulating essay, reflecting closely on current works of Johannes Fabian, Blommaert writes about 'Writing as a problem' with reference to what he calls 'African grassroots writing, economies of literacy, and globalization' (2004). Blommaert refers to Fabian's argument ${ }^{1}$ that 'the confrontation of ethnographers with written texts leads to rediscovery of orality,' and that 'this discovery is based on the realization that reading of ethnographic texts demands attention to speech and oral performance' (Blommaert 2004:643). When Fabian was confronted, 'with the erratic and less than consistent writing practices of its author, Andre Yav (a former houseboy from Lubumbashi) ... he had to

\footnotetext{
${ }^{1}$ Fabian's retrospective discussion of analytical practices from his own work on "grassroot literacy in Shaba/Katanga Congo (Blommaert 2004:643)
} 
rely on a local informant, who was asked to read the text aloud and transcribe the recording of this 'reoralization' (Bloemmaert 2004:643).

In this paper, I intend to consider both Fabian and Blommaert's argument about recoveries of orality in written texts. As Blommaert (2004:644) strongly asserts, 'We not only seem to recover orality as (possible) function of literacy, but that we may indeed want to revisit the whole issue of the function of written text.' According to Fabian (2001:66) reoralization practices addresses, 'What is negatively deplored as lack of exactitude should be seen positively as expressive of a great degree of freedom which the native speaker enjoys both as a writer and a reader.'

Of course, Blommaert does not approve of Fabian's use of the word 'freedom' for this discussion, arguing that 'freedom from normativity and writing convention valid (and oppressive) elsewhere - may obscure precisely the theme that connects the argument on functions with that on freedom: the way in which such writing practices have to be understood against the background of different economies of linguistic resources in which function-value allocation, stratification, and determination are powerful operators' (2004:644). As stated in the abstract above the idea of this paper gained impetus from having critically read a special note of condolences scribed by two women, from the Chikhutu village in Malawi, who are in a polygamous marriage situation; Mama Luhanga and Mama Luhanga - wives of Dada Patson Luhanga, a migrant worker based in Midrand, South Africa.

The note was meant to 'comfort and support' the South Africa based widow, Mme Nanabi Kegakilwe who lost her husband in August 2005. Dada Patson Luhanga had been staying on the compound of the late Rre Enoch Kegakilwe for more than twelve years. The existing verbal agreement (Mr Luhanga and the Kegakilwes) was that Dada Luhanga would work on the Kegakilwe garden every Saturday of the week while doing other menial jobs, on other days around Midrand in South Africa. As per this agreement, Dada Patson Luhanga was offered accommodation at the Kegakilwe compound pro-bono.

Three points that I will stress are:

- First, that the note in question reveals and exposes pains, hurts, and frustrations currently experienced by migrant labourers in South Africa. Recently in South Africa, the crisis of xenophobia or Afrophobia, as some critics prefer to call it and related spates of violence add to this challenge. 
- Second, I will discuss some current challenges of South Africa's migrant labourers by making use of some theories of folklore and orality. In addition, I will apply a method of discourse analysis in reading the note and debating its appropriate hermeneutics of power and identity in this case.

- Third, as Blommaert (2004:644) argues, whereas there are, 'great potential opportunities offered by literacy, it is simultaneously one of its great potential problems, precisely because of ...the economic backdrop against which writing practices must be seen.'

\section{Preliminaries}

Firstly, I would like to provide the theoretical position of my paper. Blommaert posits that 'it is clear that literacy is not just part of 'language' in general; it is a particular manifestation of language use, related to spoken language but different as a field of action' (2004:644; see also Collins \& Blot 2003). Further, Blommaert argues that spoken language, on the other hand,

'is a structured complex of meaningful sounds, the main feature of which is the fact that it disappears as soon as it has been produced, writing results in crafted artefacts that have - at least typically - the capacity to be lasting, to be archived' (2004:644).

While I agree to some posits by Blommaert here, I contest the idea that spoken language 'disappears as soon as it has been produced.' The whole idea underrates the potential of memory in general and memory strategies, as developed by local communities to record, manage and innovate their various forms of 'spoken language', either in praise poetry, musical arts performances, riddles, proverbs, or storytelling.

Blommaert (2004:645) makes a strong argument that 'The orientations to meaning that people display in spoken versus written language are again different, as are the actions that they perform in order to retrieve meaning'. In this regard, Blommaert openly admits that,

'One of the obstacles we are facing here is the strong historical 'loadedness' of writing as both the 'best' form of language - the most developed one, the most elaborate one, the 'literary' one - which is manifest, for example, in the way 
unwritten language used to be (and to some extent still is) catalogued as 'primitive' or at least 'incomplete' (Fabian 1996, Rafael 1993, Errington 2001)'.

Blommaert pictures this problem of language that 'Graphocentrism and textualism are, consequently, powerful language ideologies that organize a lot of what we pretend to detect in language and a lot of how we believe it functions onto writing at large, and thus take far too much for granted' (2004:645). The latter argument by Blommaert is very intense and critical in a sense that it exposes weaknesses of alphabetization (Blommaert 2004:645), thereby creating a falsified sense of alphabetization as closely liked development; 'a highly valued, prestige-bearing sense.'

Even in this case Blommaert has seriously taken note of the fact that 'Paradoxically, 'nonliterate' societies have long been considered to be the typical anthropological object of inquiry' (2004:669); an absurd sense of 'lingering anthropological prejudice that literate cultures were somehow less authentic, less 'anthropological', than cultures that relied strictly on oral communication (Boyarin 1992a:2)'. In this context, Blommaert (2004:645) observes:

'Within this tradition, the connection between speaking and writing was long addressed in a rather casual way'. Recent efforts are noticeable regarding emergence of studies of literacy as a different 'complex of situated practices of language use, partly responding to what happens in spoken language but partly autonomous' (Street 1995, Collins 1995, Collins and Blot 2003).

As Blommaert (2004:646) reports, many of these studies acknowledge the 'social embeddedness and situatedness of writing, and around the fact that literacy occurs in the shape of specific literacy practices performed in specific social contexts' (see also Gee 1990, Besnier 1995, Street 1995, Barton 1994).

\section{Data}

The data I shall discuss here came to me 'accidentally'. I saw a note which was nearly thrown away. A little brown note. What captured my attention and interest was how it was written. My eyes intently fell on the caption of the note: Dear Boss of Patson Luhanga. I immediately inquired from the recipient Mme Kegakilwe who burst into laughter. In her explanation she mentioned how she got the note. A note which was to 
'comfort her'. She even explained how the note helped her to grieve - using it to 'amuse and entertain herself" (go itebetsa mathata a lefatshe) after she tragically lost her husband Rre Enoch Kegakilwe. I then asked her if I could hold onto the note for a while and would return it. Of which my request was granted. I declared my intentions and interests immediately about the note. I kept the note for a period of a month. This was in June 2009 when I was employed as a Social and Institutional Specialist at the Development Bank of Southern Africa (DBSA). In July 2009, I then went back to Mme Nanabi Kegakilwe and had a conversation with her. In our series of interviews, I mentioned how interesting the note was. I asked her if she understood what the 'meaning of the note was' but she mentioned to me that she was amused by the 'English' languaging of the note. In her opinion, there was not match she could relate of pick up from the many English alphabets that filled this note. I then formally requested permission to analyse the note for academic purposes.

I was officially granted permission by the Kegakilwe family and was aware of the sensitiveness and importance nature of this note. In my research, I was conscious of the 'traversing' of confidential spaces I was letting myself into. In this consciousness I was aware that 'emotions' would be tapped and touched by what I was about to do. My research plan included doing the following:

1) Plan a series of interviews (back and forth) with both Mme Kegakilwe and Dada Patson Luhanga whose wives wrote the note to support the widow, Mme Kegakilwe during her period of mourning.

2) Plan regular visits to the University of South Africa (UNISA) Main Library to 'acquaint' myself with basic grammar and syntax of the Tumbuka language, one of the local languages spoken in Malawi. Having read the text for several times I became convinced that an entrée into it required some basic understanding of Tumbuka. Even in this case I was aware of my shortcomings - I am not a trained specialist in socio-linguistics. In addition to these limitations I need to mention the fact that I experienced financial constraints and I could not travel to Malawi with Dada Luhanga to meet with his two wives who were looking forward to my visit.

Regardless of all these challenges I decided to forge ahead and conduct the research. In my view the Tumbuka language was key to understanding and 'translating' the note. 
More importantly was the scribal form the note appeared - 'spoken than written' in this sense'. It is my intention to conduct part two of this research which will include some visitations to Malawi in the future. Of major importance were conversations I conducted with Dada Luhanga. The hand written note read:

$$
\begin{aligned}
& \begin{array}{l}
\text { Desar Boss of patson lestranga } \\
9 \mathrm{com} \text { vory nothespl to }
\end{array} \\
& \text { write cilotier wibat about } \\
& \text { heis jam serry and } \\
& \text { ven ueriser ver message } \\
& \text { of mr Bess was dieel serry } \\
& \text { mis Boss. park cr me } \\
& \text { How are recemmecied to my } \\
& \text { nome pgon and pesur ferther } \\
& \text { So d dente of hinow s cen } \\
& \text { do the boy jop wes are } \\
& \text { Fine of hou ard tour are } \\
& \text { fine from this toer he } \\
& \text { reat of tow problems sorng } \\
& \text { Boss a dool and mis unanga am } \\
& \text { very werried from vow } \\
& \text { wp to up wards. Sorny eoss } \\
& \text { part of uerur amis problems }
\end{aligned}
$$

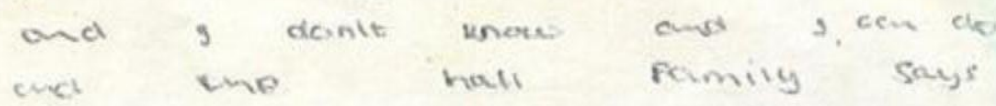

$$
\begin{aligned}
& \text { wet am sevry Boiss }
\end{aligned}
$$




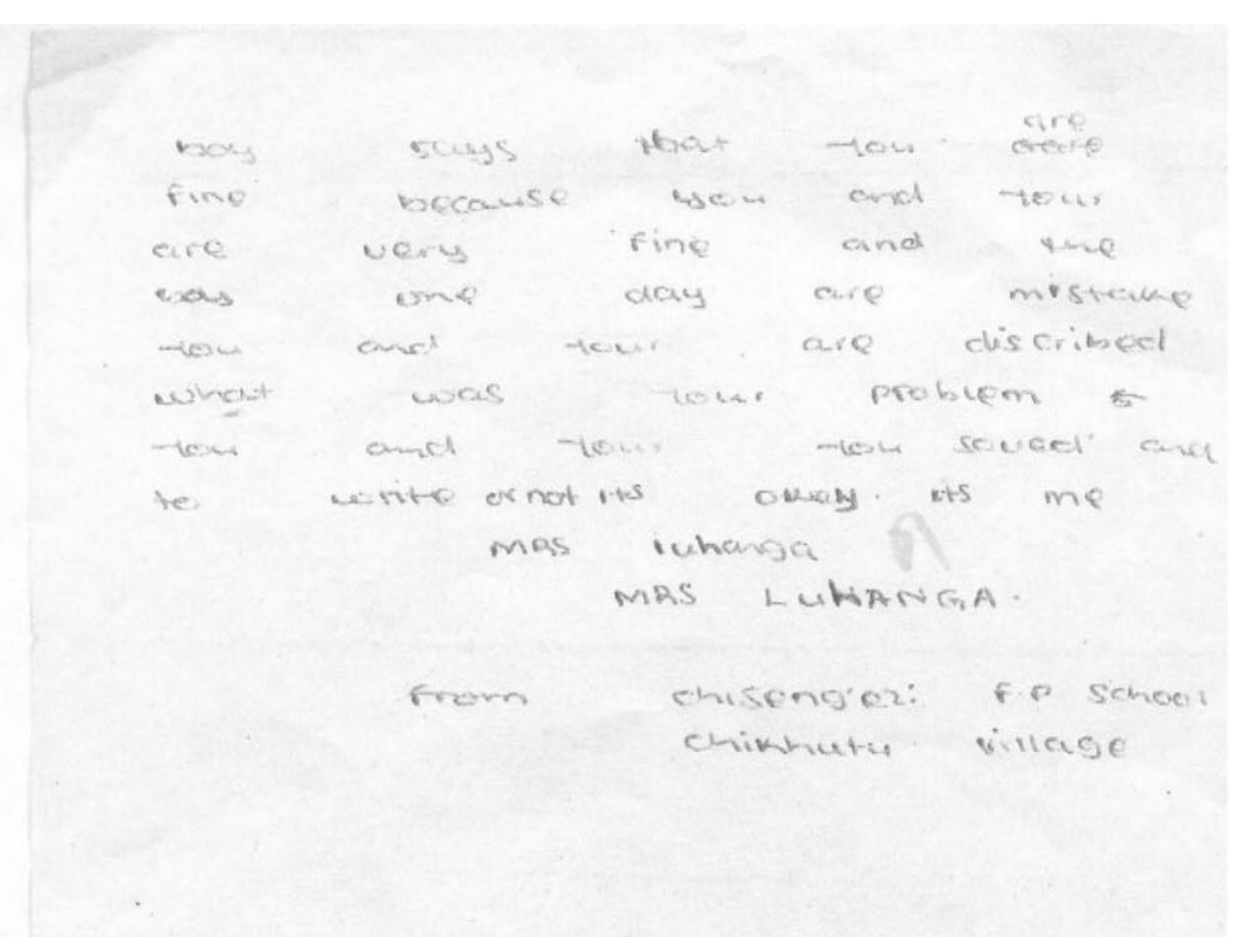

\section{Dear Boss of Patson Luhanga}

I am very not happy to

write a letter what about

you I am sorry and very worried to message

of Mr Boss was died Sorry

Mrs Boss Part of me you are recommended to my

home you and your father

So I don't know / can

do the boy $J O B$ are

fine from this year the

part of your problems sorry

Boss $1000 \%$ and Mrs Luhanga am

very worried from know up to up wards Sorry Boss

part of your this problems 
and I don't know and I can do

and the hall family says

that am sorry Boss

boy says that you are

fine because you and your are fine and the

boy one day are mistake

you and your are discribed

what was your problem

you and your you saved and

to write or its okey its me

Mrs Luhanga

Mrs Luhanga

From Chisengezi F.P. School

Chikhutu Village

\section{The story of note}

During this research, I had the privilege of interacting with Dada Patson Luhanga both formally and informally. During our series of conversations, we discussed the conditions of migrant labourers in South Africa. The most intensive conversation I had with Dada Luhanga was conducted on the Sunday morning of the 14 December 2014 at Midrand, South Africa. On this particular day I requested from Mme Nanabi Kegakilwe to conduct an interview with Dada Luhanga. Dada Luhanga was born in Malawi in the village called Mtumbuzimba. He was born in a family of three siblings; two brothers and a sister. Unfortunately, he has lost a brother. Dada Luhanga was raised in a family that was based in a community that relied on subsistence farming or agriculture ${ }^{2}$. He recalled some of the farming products that include mbila, mantonkomane, mpunga, hanyezi, nthochi and vikhawo/mayawo. These and other products were even sold at the local community market. Dada Luhanga regards himself as a committed Roman Catholic member, both

\footnotetext{
2 Subsistence agriculture or farming is when a farmer lives on a small amount of land and produces enough food to feed his or her household and have a small cash crop. The goal of subsistence agriculture is to produce enough food to ensure the survival of the individual family. If there is excess food produced, it is sold locally to other families or individuals.
} 
baptised and confirmed; and a regular communicant when he finds time to visit his family in Malawi. He was reluctant to dwell much on his early life narratives. He got married to Edna Mumba - who became his first wife in 1971. He impressed that he offered three cattle as dowry. In this union, he and his wife experienced misfortunes that included losing three children prematurely. They were advised as per their tradition, for him to look for a second wife and three cattle were offered as dowry to marry Mama Meset Soko in 1973.

Mama Meset Soko was 23 years old when she joined the Luhanga family, as his second wife. She (Meset) she gave birth to two children; a boy and a girl. Thereafter his first wife, Mama Edna Luhanga, also gave birth to two children; a boy and a girl. When asked about the life of a polygamous man, Dada Luhanga impressed that to avoid any possible conflicts; both wives should be treated equally, and be supported equally. $\mathrm{He}$ mentioned that he practices a weekly rotational plan to visit and spend his time with his two wives. Each wife has to cook a delicious dish to 'impress' him as her husband. This is done during this weekly rotational plan. Dada Luhanga also mentioned that when he sends money from South Africa to Malawi he divides it equally to avoid any possible conflict. He informed me that he had laid down mtheto wa sekhaya (family or house rules).

Dada Luhanga started to work in South Africa in the mines in the 1960s. In October 1971 he went back to Malawi to get married to his first wife and then returned back to South Africa. In 1973 he applied for a passport, which was granted, to return to Malawi to get married to his second wife. He returned back to the South African mines in 1974, and continued to work and look after his consolidated family. Dada Luhanga mentioned that he first started to live around the Alexandra Township in places that were termed Dikomponi (-ng) loosely translated as 'Compound Areas'. According to Dada Luhanga, trains were used as a means of transport in the 1960s to carry mine workers from Dikomponi to their places of work. When asked how he juggled his life between South Africa and Malawi, Dada Luhanga responded that he normally spends about three years in the country of his employment and then finds time to visit his family in Malawi for about six (6) to nine (9) months. Accordingly, this has been a consistent pattern of his

\footnotetext{
${ }^{3}$ It should be noted that much of my conversation with Dada Luhanga used the S'fanakolo lingua. Common language used in most South African mines, developed from a variety of home languages the miners spoke.
} 
life since 1974 after he married his second wife. Part of the work that Dada Luhanga did in the mines includes malaishat and longisa michini phakathi emgodinn.

Much of our conversation centred on the condolence note scribed by his wives for the attention of Mme Nanabi Kegakilwe. This part of the conversation revealed a lot about the so called literacy qualifications of Edna and Meset. Dada Luhanga explained that his first wife does not have any formal education training and cannot read or write at all in a formal sense. Meset, on the other hand, passed Standard three; a category of educational qualification in Malawi that offers learners basic reading and writing skills. In addition, Meset was involved in a number of community activities that include serving on the school committee. Dada Luhanga impressed that Mama Meset is, 'very much educated since she has to attend meetings, take and make minutes and is expected to sign very important documents, she is the educated woman of the family and this does not at all threaten the existence of Edna. They both complement each other. In fact, she helps Edna. I have got no problem at all. I love the way things are. We have no problems at home'.

\section{Reading the note}

One should hasten to admit that my initial reading of the note exposed my prejudices in terms of 'spoken language' versus 'written language'. Despite my former training on orality, I could not help it but subject my reading to prejudicial tendencies whose textualised criteria included coherence, transparency, and correctness - in short, those discourse features which we associate with truth (Blommaert 2004:654). I then changed my focus of analysis and dealt with two major issues: First, the function of the 'text' and, second, an attempt to derive meaning from the 'text'. Blommaert explains that 'What is understood by 'reading' can differ across communities and contexts, as well as across genres' (2004:654).

\footnotetext{
${ }^{4}$ Generally translated as 'carrier' - thereby giving the meaning of a transport assistant underground the mine shaft.

${ }^{5}$ General fixing or repairing of broken machines under-ground.
} 


\section{Dear Boss of Patson Luhanga}

1. I am very not happy to

2. write a letter what about

3. you I am sorry and very worried to message

4. of Mr Boss was died Sorry

5. Mrs Boss Part of me you are recommended to my

6. home you and your father

7. So I don't know I can

8. do the boy JOB are

9. fine from this year the

10. part of your problems sorry

11. Boss $1000 \%$ and Mrs Luhanga am

12. very worried from know up to up wards Sorry Boss

13. part of your this problems

14. and I don't know and I can do

15. and the hall family says

16. that am sorry Boss

17. boy says that you are

18. fine because you and your are fine and the

19. boy one day are mistake

20. you and your are discribed

21. what was your problem

22. you and your you saved and

23. to write or its okey its me

24. Mrs Luhanga

25. Mrs Luhanga

26. From Chisengezi F.P. School

27. Chikhutu Village 


\section{An attempted structural and literary analysis of the note}

a) The note is divided into four parts: the caption, the message of the note, autosignature of the authors and address of the authors. The caption of the note is affectionately captured: Dear (see Tumbuka nyama, vinyama or paweme) - the authors 'reach out' to another woman whom they have not seen but heard stories about her from the conversations they had with their husband. The recipient of the note is characterized as 'lovable, dearest and, for that matter, a greatly valued person. Interestingly, authors here do not use her name to address her but refer to her as Boss of Patson Luhanga'. In this case Mme Kegakilwe is the $\mathrm{Ng}^{\prime}$ ome (Tumbuka for the one in charge'). Here, power relations are clearly mapped out. Mme Kegakilwe carries with her power, and their family welfare cannot be compromised. Also it becomes evident that the two wives of Dada Luhanga are aware of the power relations that are at play here. Part of this awareness has to do with the fact that they acknowledge that their 'bread-winner' and father of their children has to be represented well. They cannot afford to capture this as: Dear Boss of our husband.

b) The first opening lines of the note are telling:

1. I am very not happy to

2. write a letter what about

3. you I am sorry and very worried to message

4. of Mr Boss was died Sorry

The first line expresses feelings of the authors: / am not happy to. Using the English language to convey their collective expression of condolence here seems problematic, as that the authors are married to one husband; Dada Patson Luhanga. It is likely that had they used their local language, Tumbuka, this could have been easier to express a sense of togetherness and collectivity. They scribed the note collectively. This is despite the fact that at times matako ghawi ghaleka cha ku kwenthana (two buttocks cannot avoid friction) or vitotoka vigona mu chikuto chimoza cha (Two cockerels cannot sleep in one cage); even then people should learn to live together in spite of any problems they might have; living out the common expression: umoza ndi nthazi (oneness is strength). 
During one of the interviews with Dada Luhanga he mentioned that both wives were affected by the passing away of Rre Kegakilwe.

Clearly, both wives had never experienced the 'pain' of being a widow except drawing from the experiences of their respective mothers. Both wives are aware that nyifwa ndi chola (death is everywhere) Regardless, both women are not happy and express their sadness after the passing away of their husband's 'boss' and 'benefactor'; a patron for that matter. Clearly according to Dada Luhanga the writing of the letter became a consultative process and procedure: write a letter what about, according to line 2 of the note. In line 3, the authors deepen their expression of sadness, to make it sound repetitive. Immediately in the same line they mention: very worried to message. The latter refers to the time they heard about the passing away of Rre Kegakilwe; then they became worried. It is not clear whether this 'worry' had to do with the 'possible uncertainty' about the future of their husband or had something else. This is strengthened by line 4: of Mr Boss was died sorry. I asked Mme Kegakilwe in this regard and she confirmed that Dada Luhanga cried uncontrollably during the funeral of Rre Kegakilwe and mentioned much about his future at their house. She (Mme Kegakilwe) had to assure Dada Luhanga that his future stay at the compound was not going to be affected by the passing away of Rre Kegakilwe.

c) The following lines form a unit:

5. Mrs Boss Part of me you are recommended to my

6. home you and your father

7. So I don't know I can

8. do the boy JOB are

9. fine from this year the

10. part of your problems sorry

11. Boss $1000 \%$ and Mrs Luhanga am

12. very worried from know up to up wards Sorry Boss

13. part of your this problems

14. and I don't know and I can do

15. and the hall family says

16. that am sorry Boss

17. boy says that you are 
18. fine because you and your are fine and the

19. boy one day are mistake

20. you and your are discribed

21. what was your problem

22. you and your you saved and

23. to write or its okey its me

In this structure of the note the authors refer to Mme Kegakilwe as Mrs Boss. This enforces the title of the note: Dear Boss of Patson Luhanga. In lines 5-6 there are indications of a 'close family'; Mrs Boss and her family are well known to the Luhanga family, hence: Part of me you are recommended to my home you and your father. It is not clear what is meant by father (Dada) in this context. Lines 7 and 8 one present an interesting part of the message: So / don't know / can do the boy JOB. Mamas Edna and Meset refer to their husband as 'boy' (mpesuka). The interpretation remains a derogatory one. Clearly Dada Luhanga shared with them some political landscaping and languaging around class and race in South Africa. 'Boy' is a derogatory form of address to men and stems from the South African socio-economic and political situation of struggle and apartheid, where black men were generally referred to as 'boy', irrespective of their age, by those in power (the white people). Thus this term contains a racialized tone with strong under-tones of disrespect and ill-treatment. As indicated, the Luhanga family had been fully informed about the South African class struggle and racialized workers' conditions. In this long socio-economic and economic periodization of experience about life in South Africa, Dada Luhanga observed and was equally affected by the situation of apartheid. This situation led to the time after 1994 when the new democracy was ushered in. Stories of suffering, survival and hardships were transported from South Africa to Malawi, in the Chikhutu village.

Mama Edna and Mama Meset wrote the note after 1994 when South Africa entered into its democratic phase. Despite Democracy, not much has really changed on the mines; boys are still boys and baases are still baases, hence their husband is still a 'boy' doing a 'boy job', except that there is sturdy rise of the black middle class in the country as a whole. The Kegakilwe family form part of the emerging black middle class. Race categories such as 'boy', 'girl', 'baas', and 'boss' are still maintained and mainstreamed in the newly constituted South African democracy. Even the so-called 'ordinary' people 
beyond the South African borders are aware of the structure of socio-political and economic inequalities of South Africa. Both Mama Edna and Meset 'play along', as displayed in the note.

d) The conclusion:
24. Mrs Luhanga
25. Mrs Luhanga
26. From Chisengezi F.P. School
27. Chikhutu Village

The last four lines (24-27 lines) of the note conclude it. First the auto-signature followed by the address indicating where the note came from. To show that this note was collectively 'written' their names are indicated (MRS LUHANGA) - in capitals to show that she is the first wife and (Mrs Luhanga) - mostly lower case - indicating that she is the second wife. The Chisengezi FP School is where letters are posted and received.

\section{A case for a different kind of writing}

The note presents a different writing mode; a writing-back process, or a narrative-note (polelo). Such narrative discourse opens a door for the reader into the narrator's world. The note distinguishes between histoire, recit and narration, to account for the analytical categories used in any narrative situation. In the note one is confronted by story, (oral) text and narration. For purposes of this paper, both the story and (oral) text interplay. The textual narration of the above note stands in relation to both story and narration. Further to this are three categories that should be noted in this regard: Time, characterisation and focalisation. In this case time and characterisation stand in relation to the story and focalisation to the narration of the above note. Time category concerns the textual arrangement of the event component of the story in the text.

Definitely, the authors of the note do not accurately correspond to the logical chronological succession of events when they wrote the note. The discourse of the authors is patterned in terms of order, duration, and frequency. The order patterns of the note specify analeptic (flashbacks) and proleptic (foreshadowing) relations between the story and text-time. Duration specifies the difference in time between events that took place in the story and at various textual levels. Lastly, frequency specifies the 
number of times the events in the story are recounted in the text. In this regard 'initiation' as an event noted in the text is repeated several times. Lastly, focalisation offers the reader or hearer an 'angle of vision' through which the story is filtered in the text, and it is verbally formulated by the authors. As Blommaert (2004:662) concludes:

'Africa has become a writing continent ...But its products of writing may not be directly accessible as bearers of historical, cultural, and social knowledge, and consequently we may fail to see, detect, and identify documents as bearers of such knowledge.'

\section{Concluding remarks}

Having analysed the note, one reads the current South African socio-political and economic landscaping as becoming complex. Historically, liberation struggles intensified in the country for centuries ago. These periods of struggle for liberation were not without challenges. Killings and violence engulfed most communities. All kinds of theories were meted to explain such carnage and spate of violence. Reflections at the time became 'heated' on how an oppressive colonial system undermined African human life should be dismantled. The current African situation has become complex. New issues and challenges have emerged. An HIV/Aids pandemic remains a challenge. Poverty and unemployment remain stubbornly high. The economic storm clouds are far from disappearing. Crime is not only soaring, but increasingly violent. There is a pervasive air of public corruption. In some democratically consolidated states such as South Africa efforts to make the public service more efficient have failed. Often one notes with a sense of disappointment that democratic institutions are battered. The abuse of children, women and the aged has reached terrifying levels.

Communities are paralyzed by the feeling of anxiety, drift and foreboding of imminent collapse among communities. Definitely most communities are facing a broken state in South Africa. There are voices calling and demanding for fresh ideas and a new direction - which appears to be spectacularly lacking. Spate of violence and protests by communities across the countries against sluggish governments delivery of services, indifferent officials and corruption are also likely to continue. Restlessness grips the entire continent. It is giving a strong sense of uncertainty, discontentment and doubt. Even to the point of seriously questioning the validity of the some of the South African 
democracy that have been fought for many years inside and outside the continent. The latter in essence pushed a number of people to do African regional self-introspection and self-critical engagement about the already established South African history of protest and affirmation.

This constant reflection is noted in various forms that include local narratives and anecdotes and also reported stories of anger, frustration, anguish and agitation. This came to the point where public infrastructures were destroyed in the process of staging these protests. One noticed that there were two kinds of protests: first "social delivery protests", which often spring up as road blockades, burning tyres, trashing vehicles, scattering rubbish and then die away, and the activities of social movements, which assume a more ongoing and organized form. These protests have been called "social delivery protests."

While one agrees with generalised comments raised on the South Africa's 'growing democracy' but one is inclined to read that there is a level of dissatisfaction and disappointment among communities. The fact remains - all is not well. A serious rethinking has been necessary to push African leaders to the drawing board and start to re-strategize on a number (on) of issues: reflect on the mandate, and consider honestly on the servitude task for the people of Africa, have a better way to re-articulate policies around public service, review the human capability plans, have a well-shaped monitoring and evaluation plan in place. On another level there has always been a need to distinguish between political leadership and administrative task. Although at times the two are linked but should not be confused.

On a different level the South African situation is compounded by regional integration developments. The note accounts for this developing situation of migration and regional integration. It becomes important to note the importance of orality and reoralisation in reading and interpreting the current South African socio-economic and political situation. The analysis of the helped to bring together a social analysis approach and the study of orality. As argued in the paper, orality is affirmed as the foundation and development of oral communities; hence, the focus on the note. As demonstrated above words in writing, in their true sense, are not solely made up of letters but of their functional units or phonemes. This fact challenges the current view of language as merely founded on written rather than phonetic nuances. Language largely is, and will continue to be, an oral phenomenon. Written traditions or oral expressions have 
continued to exist and still exist without any writing activity at all - or demonstrated above are both folklorised and reoralised. Future research theories and methodologies should take into account the bearers of knowledge in its totality - including issues of historical, cultural, and social knowledge in taking this process forward unless we risk to 'fail to see, detect, and identify documents as bearers of such knowledge' (Blommaert 2004:662).

\section{List of References}

- Besnier, N (1995). Literacy, emotion, and authority: Reading and writing on a Polynesian atoll. Cambridge: Cambridge University Press.

- Blommaert, J (1999). Reconstructing the sociolinguistic image of Africa: Grassroots writing in Shaba (Congo). Text 9:175-200.

- Blommaert, J (2001a). Investigating narrative inequality: African asylum seekers' stories in Belgium. Discourse \& Society 12:413-49.

- Blommaert, J (2004a). Grassroots historiography and the problem of voice: Tshibumba's 'Histoire du Zaire'. Journal of Linguistic Anthropology 14:6-23.

- Blommaert, J (2004b). Discourse: $A$ critical introduction. Cambridge: Cambridge University Press.

- $\quad$ Boyarin, J (1992a). Introduction. In Boyarin (ed.), 1-9.

- Boyarin, J (ed.) (1992b). The ethnography of reading. Berkeley: University of California Press.

- Collins, J \& Blot, R (2003). Literacy and literacies: Texts, power and identity. Cambridge: Cambridge University Press.

- $\quad$ Errington, J (1990). Colonial linguistics. Annual Review of Anthropology 30:19-39.

- Fabian, J (1990). History from below. Amsterdam: John Benjamins.

- Fabian, J (1996). Remembering the present. Berkeley: University of California Press.

- Fabian, J (2001). Keep listening: Ethnography and reading. In his Anthropology with an attitude, 53-69. Stanford: Stanford University Press. 
- $\quad$ Rafael, V (1993). Contracting colonialism: Translation and Christian conversation in Tagalog society under early Spanish rule. Durham: Duke University Press.

- Street, B (1995). Social literacies. London: Longman.

- Tumbuka-Tonga-English and English-Tumbuka-Tonga Dictionary compiled by Wm. Y Turner, Central Africana Limited, Blantyre, Malawi (1996) - with a new preface by Alex B Chima.

\section{AUTHOR'S CONTACT:}

MASOGA, Mogomme A.

Professor,

School of Human and Social Sciences

University of Venda

Email: alpheus.masoga@univen.ac.za 